\title{
Augmented reality applications: A Meta-analysis and thematic analysis
}

\author{
Veli Batd 1 \\ Kilis 7 Aralık University, Muallim Rıfat Education Faculty, Kilis, Turkey, veb_27@hotmail.com \\ Tarık Talan \\ Gaziantep Islam, Science and Technology University, Faculty of Engineering and Natural Sciences, \\ Gaziantep, Turkey, ttalan46@ hotmail.com
}

\begin{abstract}
The purpose of this study is to determine the effect of augmented reality (AR) applications on academic success through meta-analytic and thematic analysis. 51 items from 45 studies conducted between 2013 and 2019 were examined in different databases on the effect size of AR in relation on academic success, education level, and duration of the application. The effect size was found to exist at a medium level, considered to be significant which means that AR has positive effect on academic success. In terms of thematic analysis, with reference to common codes and themes found in qualitative studies conducted both nationally and internationally, qualitative findings were obtained. An emphasis on the effect of AR on learning, class environment and affective dimensions was made, together with a consideration of some limitations. It was stated that learning environments could be arranged in such a way that students could be motivated through the use of AR, leading to permanent and solid learning. Therefore, careful and planned use of AR can be said to encourage success.
\end{abstract}

Keywords: $\quad$ Augmented reality, Academic success, Meta-analysis, Thematic analysis.

\section{Artırılmış gerçeklik uygulamaları: Bir meta-analiz ve tematik analiz}

ÖZ Bu araştırmanın amacı artırılmış gerçeklik uygulamalarının akademik başarıya etkisini meta-analitik ve meta-tematik yöntemlerle belirlemektir. Bu bağlamda, artırılmış gerçeklik ile ilgili 2013-2019 yılları arasında yapılmış ve çeşitli veri tabanlarından tarama sonucunda ulaşılan 45 çalışmadaki 51 verinin başarı üzerindeki etki büyüklüğü ile öğretim kademesi ve uygulama süresi bağlamında da incelenmiştir. Etki büyüklüğü orta düzeyde bulunarak anlamlı ve etkili bulunmuştur. Bu bulgu artırılmış gerçekliğin akademik başarı üzerindeki etkisinin olumlu yönde etkili olduğunu göstermektedir. Diğer yandan araştırmanın meta-tematik analizi için yine ulusal ve uluslararası alanda, nitel yönlü çalışmaların ortak kod ve temalarından alıntılar yapılarak nitel bulgulara ulaşılmıştır. Artırılmış gerçekliğin öğrenme/sınıf ortamına, duyuşsal boyuta etkisi ile birtakım sınırlılıkların olduğu vurgulanmıştır. Öğrenme ortamlarının artırılmış gerçeklik ile motive eden, kalıcılık sağlayan şekilde düzenlenebileceği, somut öğrenmelerin gerçekleşebileceği ifade edilmiştir. Bu nedenle dikkatli ve planlı artırılmış gerçeklik kullanımının, beraberinde başarıyı getirebileceği belirtilebilir.

Anahtar Artırılmış gerçeklik, Akademik başarı, Meta-analitik analiz, Tematik analiz. 


\section{INTRODUCTION}

The recent developments in information and communication technologies and the changes in student profiles have brought about the utilization of appropriate settings and technologies that diversify, support and enhance education. One of the newest technologies that has the potential to bring together the real and virtual world and which can be used for many fields as medical education (Barsom, Graafland \& Schijven, 2016) or educational purposes both inside and outside the classroom is "Augmented Reality". AR technology, which is likely to be used actively in the future and which offers rich learning settings (Alcañiz, Contero, Perez-Lopez \& Ortega, 2010), is one the applications that has the potential to provide pedagogical value and introduce new methods in the field of education.

AR can be defined as a technology by which real world settings and virtual objects come together simultaneously in an interactive learning environment (Azuma, 1997; Chen \& Wang, 2015; Sommerauer \& Müller, 2014) and can be accessed by the user. AR can be briefly identified as real settings (Somyürek, 2014) that are enriched with virtual objects or the enhancement of an individual's perception of reality (Graham, Zook \& Boulton, 2013) through the use of technology. In other words, AR offers multi-media content by simultaneously adding a digital layer such as audio, text, graphics, video, GPS location information, and 3D models onto real world images. As such, the most important property of AR is that of enhancing and augmenting reality by providing information which cannot be perceived by humans under normal conditions (Azuma, 1999). Thus, individuals using AR technology can see, hear, feel, smell, and even taste virtual experiences in the real world (Van Krevelen \& Poelman, 2010). Thus, when properly integrated into educational environments, AR is considered to support authentic learning and constructivist learning approaches. Though it has been described differently by various researchers, in order for an application to be considered to be AR, it needs to have certain characteristics. AR has three essential properties: (i) combining virtual and real objects in real settings, (ii) working real time interactively, and (iii) aligning real and virtual objects (Azuma, 1997). At this point, AR can be considered as a visualization technique in which the real and virtual objects interact collaboratively. This interaction occurs with the integration of virtual concepts and objects into real world setting.

AR provides the users with the opportunity to simultaneously see a real setting together with virtual objects added to this setting. It is a technology which has been used in recent years in every field where human life is involved. In addition to being used for military purposes, AR is utilized actively in such diverse fields as industry, engineering (Liu, Cao, Tse \& Xu, 2017), aviation, entertainment, tourism and medicine (Cardos, David \& David, 2017). One can also observe its active application in various disciplines in education in sciences such as physics, chemistry, and biology, in social sciences such as history and health sciences, and in mathematics and language education. Consequently, AR, a new generation of technology with its range of unique features, has drawn the attention of researchers in a short time in terms of its application in education ranging from primary school to university use. The most prominent of these features supporting many pedagogical approaches include authentic learning in educational environments (Wu, Hwang, Yang \& Chen, 2013; Yuen, Yaoyuneyong \& Johnson, 2011), situational learning (Chen \& Tsai, 2012; Dunleavy, Dede \& Mitchell, 2009; Taşkıran, Koral \& Bozkurt, 2015; Wojciechowski \& Cellary, 2013; Wu et al., 2013), problem-based learning (Dunleavy et al., 2009), structural learning (Delello, 2014; Kerawalla, Luckin, Seljeflot \& Woolard, 2006), offering the opportunity to learn by doing and experiencing (Dunleavy et al., 2009; Dunleavy \& Dede, 2014; Ersoy, Duman \& Öncü, 2016; Taşkıran et al., 2015; Wojciechowski \& Cellary, 2013), being student-centered (Delello, 2014), and supporting learning by questioning (Fleck, Simon \& Christian Bastien, 2014; Wojciechowski \& Cellary, 2013). The utilization of AR is considered beneficial due to the advantages it offers such as making complicated information understandable through the use of visualization (İbili 
\& Şahin, 2013), teaching subjects which cannot be observed directly (Wu et al., 2013), the consideration of expensive and dangerous situations safely and at low cost (Walczak, Wojciechowski \& Cellary, 2006), and making abstract concepts concrete (Lee, 2012; Wu et al., 2013). Furthermore, AR technology offers flexible opportunities for students to learn anytime and anywhere (Kamphuis, Barsom, Schijven \& Christoph, 2014; Schrier, 2006), and creates a comprehensive and critical learning environment through creative thinking, critical thinking, problem-solving, and developing communicative skills via practices based on mutual cooperation (Ivanova \& Ivanov, 2011; Schrier, 2006). In addition, in some studies it is stated that the ability to combine physical and virtual worlds simultaneously can contribute to children's social skills and academic development (Serino, Cordrey, McLaughlin \& Milanaik, 2016). Furthermore, it leads to deeper learning by providing three dimensional images of objects allowing consideration from different locations and angles, improves students' spatial skills, and helps them acquire practical application skills (Cheng \& Tsai, 2013; Radu, 2014; Yen, Tsai \& Wang, 2012). Thus, such potentials of AR technology in education have caused the number of research efforts to increase, leading to its more active use in recent years.

On the other hand, some studies point to some of the challenges and limitations of AR in addition to the many educational opportunities. In the literature it has been stated that the application is limited due to the difficulty of developing content and to the limited access to digital settings and hardware resources during content development (Azuma, 1997; Küçük, 2015). In addition to these limitations, other shortcomings of AR relate to the hardware and technical problems experienced during the application (Akbaş \& Güngör, 2017; Rabbi \& Ullah, 2013; Van Kreveleen \& Poelman, 2010; Wu et al., 2013), the individual's lack of knowledge about the device and application (Akkuş, 2016; Lin, Hsieh, Wang, Sie \& Chang, 2011; Taşkıran et al., 2015), and the lack of technological material, high cost of software and wearable technologies (Billinghurst \& Dunser, 2012; Özarslan, 2013). Additionally, problems that hamper students' socialization and communication processes (Radu, 2014; Y1lmaz \& Batd1, 2016), and some educational problems experienced during learning such as the increase in cognitive load in multiple and complicated tasks (Cheng \& Tsai, 2013; Dunleavy \& Dede, 2014), can be listed as the negative features of AR. Teachers and learners who believe that they will have difficulty in overcoming such limitations may be unwilling to enter the AR environment (Yuen et al., 2011). To this end, such negative features must be identified and eliminated and steps should be taken to overcome them. In addition, applications need to be pretested in order to make effective use of AR technology. Otherwise, any deficiencies experienced during application have the potential to cause significant setbacks as they will make perceptions of the practicality of AR technologies difficult to overcome. Also, to succeed with the use of AR, materials must be designed appropriately and solidly in accordance with the principles of learning and teaching.

\section{The Purpose and Significance of the Study}

For the integration of new technologies and education, and in order to ensure their effective use in educational settings, mobile applications that do not lose educational focus, do not prevent students' interaction with printed books, allow more collaborative and mutual interaction opportunities for students, and have video and player features, are essential. In this context, AR applications seem to be practical on smart phones, and on mobile devices such as tablets and computers. Considering the capability of AR applications which enable many experiments and subjects that cannot be accomplished in the classroom due to high cost, difficulty of being carried out in practice in the real world, and to be used in combination through the interaction of printed materials and mobile devices, AR technology is expected to contribute positively to effective education.

Comprehensive and detailed research into the efficiency of AR applications in educational settings, and the difficulties and problems faced during application, needs to be done, and the results need to be assessed. For this reason, a detailed analysis is necessary in order to determine the relationship between AR and its success in all aspects, by examining the efficiency of AR in education comprehensively and holistically. The data to be obtained from this research is believed to not only provide necessary information to educators who wish to use AR technology, but also act as a guide to future studies. 
In this study, it is seen that AR is carried out in two dimensions as meta-analysis and meta-thematic analysis. When the literature is reviewed, it has been found that there have been meta-analysis studies conducted on AR (Akçayır, 2018; Radu, 2014; Tekedere \& Göker, 2016). However, the fact that no studies have been reached in which meta-analysis and meta-thematic dimension are used together differentiate our current research from other studies and reveal the original aspect of the present research. With the addition of the meta-thematic dimension to this research, it was ensured that the ideas with common qualifications considering the effect of AR were gathered in the process.

On the other hand, in most of the meta-analytical studies related to AR in the literature, only the effect of AR on academic success aspect was discussed, but other dimensions were not mentioned (Akkuş, 2016; Alcañiz et al. 2010; Radu, 2014). Whether the effect of AR on academic success changes according to the education level and application duration or not can be seen after this moderator analysis. It was tried to answer the question of "Does duration or education level have significance in AR applications?". Thus, in the present study, the effect of AR on academic success was analyzed by moderator analysis and it was examined. In this sense, a more detailed and comprehensive analysis shows that there is a different aspect from other studies.

The methodological process of this study, which was conducted to examine the AR applications with meta-analytical and meta-thematic analysis, is similar to the study conducted by Batd1 and Batd1 (2015). In this study, besides the academic success, the subject area and the application periods have been examined as moderator analysis. But in the present study, in addition to the application period, which gives information on how long this application should be implemented to determine the effectiveness of $\mathrm{AR}$, it is also taken into consideration that which education levels can be better integrated to AR process and more efficient results can be created. Although this situation is similar in terms of methodological process, it can be considered to be different in terms of content and subject.

Within this context, the primary purpose of this research is to holistically study the research conducted on the use of AR in education. Thus, a meta-analysis of the research which has examined the effect of AR on academic success is aimed for. In line with this primary aim, answers to the following research questions were sought:

What is the distribution of the descriptive statistics in the research revealed by the meta-analysis?

What is the general level of the effect size of AR on academic success?

With regard to the education level, what is the effect size of AR on academic success at various levels?

From the perspective of application duration, what is the effect size of the duration of the use of AR on academic success?

To what extent does the thematic examination of documents reveal the effectiveness of AR?

\section{METHODOLOGY}

\section{The Pattern of the Research}

In this study, meta-analytic and thematic analyses were performed in order to determine the effect of AR applications on academic success. The fact that the research has two dimensions involving both qualitative and quantitative features is believed to contribute to the reliability and validity of the results 
of the research. As such, the meta-analysis method was primarily employed in the research to determine the effectiveness of AR applications. The meta-analysis method, also referred to as the synthesis of qualitative research, enables us to combine all research involving similar subjects and different sample quantities related to AR into a research on the effect size. Cohen's d is a sample-based index which consists of standardized differences between the means of an experimental group and a control group in a way that cannot be achieved by test statistics. Some changes made by Hedges and Olkins (1985) reduce the biases resulting from different sample quantities associated with different research efforts. Thus, meta-analysis is defined as an approach which aims to estimate how different the practices in one research effort are compared with others, through a wide range of similar research efforts and related differences. Another advantage of meta-analysis is that it makes moderator changes by examining detailed relationships that may be found in the data (Bernard et al., 2004). Although there are many methods of reviewing the literature, the main difference between meta-analysis and other methods of literature reviewing is that it is based on statistical techniques and quantitative data. In addition, the second dimension of the research relates to the context of qualitative meta-thematic analysis. Metathematic analysis can be explained as a qualitative method on a certain topic in the literature involving a combination of the results of selected studies in terms of certain criteria (Batd1, 2017). As a result of the researches that have been carried out at this point in time, some international studies which have been conducted similarly to meta-thematic analysis and which are described as meta-synthesis (Erwin, Brotherson \& Summers, 2011), systematic review (Philips, Lee, Ghobadian, O'Regan \& James, 2015) or thematic meta-analysis (Lehner \& Kaniskas, 2012), have been accessed. However, the difference between the contents of these research efforts in terms of meta-thematic analysis process, form of code and theme, the way the data was used, and the current research, all point to the distinctive characteristic of our research results compared to the results of other researchers.

\section{Data Collection Process and Analysis of Data}

In the data collection process, databases and search criteria were determined to access and examine studies related to AR, primarily in the academic success dimension. In this context, the databases of Web of Science, ERIC (EBSCO), Science Direct, Wiley Online Library Full Collection, Springer LINK, Scopus (A\&I), Taylor \& Francis Online, ProQuest and the Higher Education Council (YÖK) National Thesis Center were searched. As a keyword in the scanning process, concepts such as "augmented reality" and "augmenting reality" were used, and studies in Turkish and English were selected. The publication years of the studies were determined to be 2013-2019. The reason for preferring the year of 2013 is that after the year of 2013, AR has begun to be used more widely in daily life for due to the invention of Google glass (Rauh, Zsebedits, Tamplon, Bolch \& Meixner, 2015). It was also aimed to access to the latest research in the literature. The data obtained during the data collection process were given in accordance with the Prisma flow diagram in shown in Figure 1 (Moher, Liberati, Tetzlaff, Altman \& Prisma Group, 2009). 


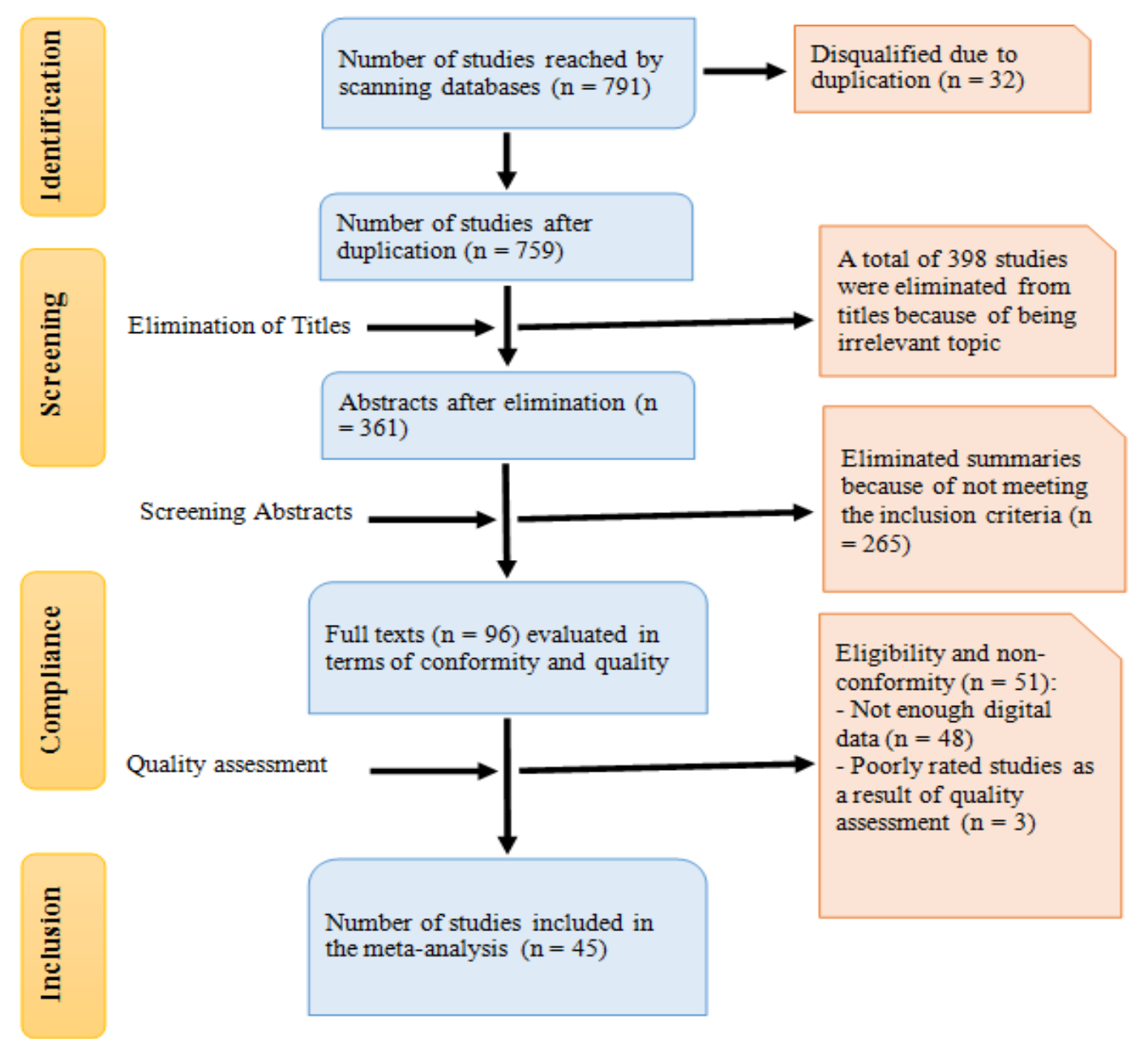

Figure 1. Flow Chart for Selection of Works (Flow Diagram)

At the end of the data collection process, 18 (40\%) theses and 27 (60\%) articles which amounted to a total of 45 studies that met the criteria for meta-analysis and included enough information necessary for determining the quantitative effect were analyzed for the effect size. In some studies, included in metaanalysis, the results of these applications were evaluated separately because the effect of AR on academic success was assessed differently for different sample groups. The study included 51 items from 45 studies. A total of 791 studies were eliminated as a by the scanning process due to duplication, being irrelevant, and not meeting inclusion criteria. In the selection of studies included in the metaanalysis, criteria with regard to the descriptive data necessary for the calculation of impact sizes on academic success were taken into account.

In the meta-analysis study, CMA and MetaWin software were used for calculation and graphical operation purposes. In addition, the Thalheimer and Cook (2002) classification was used to interpret the effect size values. In the meta-analysis dimension of the study, the reliability of the inter-rating was aimed to calculate. For this reliability, except from the researcher of the study, another rater who has experiences in meta-analysis and works at a university as an academician examined all the studies independently. Finally, both raters discussed inconsistencies and after reaching a consensus, the reliability was tested via the interrater reliability formula (Miles \& Huberman, 1994). The value was found to be as $100 \%$ which means that the studies were included and analyzed reliably.

In order to contribute to the internal validity of the study, thematic analyses were conducted by scanning qualitative studies. In this context, qualitative studies in the literature relating to AR were reviewed, and 19 studies were accessed as a result. The qualitative data of the research were analyzed by a content analysis method involving the use of the MAXQDA qualitative data analysis program. Content analysis 
is the making of cognitive schemas meaningful for the reader through the use of textual analysis. In addition, content analysis is based on the understanding that word groups reveal themes, and that the keywords come together and reflect the relationship between the basic concepts (Weber, 1990). Content analysis methods in which qualitative data are examined in detail was explained by Yıldırım and Şimşek (2013) as the data collected in the research in order to identify concepts and relationships. In this context, in the current research, databases such as Web of Science, ERIC (EBSCO), Science Direct, Wiley Online Library Full Collection, Springer LINK, Scopus (A \& I), Taylor \& Francis Online, ProQuest and the Higher Education Council (YÖK) National Thesis Center were searched, the results of the accessed studies were examined, and the common expressions and themes cited were re-created into themes and codes. The expressions in the studies where the related themes and codes were quoted were given in the text in the current study to support the codes and themes. For example, 5-223 refers to the quotation from page 224 of study number 5. Compliance values (Cohen Kappa) between the data encoders were calculated to ensure the reliability of the meta-thematic process based on document analysis (Viera \& Garrett, 2005). At this point, the compliance values calculated for each theme were also found in relation to the limitations of AR (.792) and to its contribution to the affective dimension (.707), the learning environment (.754) and the classroom environment (.863). These values being evaluated at a good / very good level mean that the data coding of the research was done in a reliable way (Appendix 1).

\section{RESULTS}

In this section, firstly, the results of the meta-analysis findings and the descriptive statistics of the studies included in the study are given. The calculated effect size values and changes in subcategory groups are then examined. After the presentation of the meta-analytical findings, the results obtained by thematic analysis related to the use of AR in education are included.

\section{Descriptive Statistics of Studies}

Descriptions examined in this research consist of education level, application period, type of publication, study year, subject area and sample size. Table 1 shows descriptive statistics for these variables.

Table 1.

The Frequency and Percentage Values of the Studies

\begin{tabular}{lcclcc}
\hline Options & $\mathrm{f}$ & $\%$ & Options & $\mathrm{f}$ & $\%$ \\
\hline Education Level & & & Year & $5 / 8$ & $11.1 / 17.8$ \\
\hline Primary School & 11 & 24.4 & $2013 / 2014$ & $7 / 9$ & $15.6 / 20.0$ \\
Secondary School & 14 & 31.1 & $2015 / 2016$ & $5 / 9$ & $11.1 / 20.0$ \\
High School & 7 & 15.6 & $2017 / 2018$ & 2 & 4.4 \\
University & 13 & 28.9 & 2019 & & \\
\hline Duration of Application (Weeks) & & Subject Area & 26 & 57.8 \\
\hline $1-4$ & 17 & 37.8 & Science & 3 & 6.7 \\
$5-6$ & 5 & 11.1 & Maths & 2 & 4.4 \\
$7-8$ & 3 & 6.7 & Social Sciences & 6 & 13.3 \\
$9-18$ & 4 & 8.9 & Foreign Language & 5 & 11.1 \\
Other & 3 & 6.7 & Computer & 3 & 6.7 \\
Unspecified & 13 & 28.9 & Other & & \\
\hline Publication Type & & & Sample Size & 13 & 28.9 \\
\hline Articles & 28 & 62.2 & Small Sample $(\mathrm{n} \leq 50)$ & 23 & 51.1 \\
Master's Thesis & 9 & 20.0 & Medium Sample $(51 \leq \mathrm{n} \leq 100)$ & 9 & 20 \\
Doctoral Thesis & 8 & 17.8 & Large Sample $(\mathrm{n} \geq 101)$ & & \\
\hline
\end{tabular}


Table 1 shows that the majority of the 45 studies included in the meta-analysis related to secondary school $(31.1 \%)$ and university (28.9\%), while the least number of studies (15.6\%) related to high schools. It was observed that the studies were concentrated in the period 2014-2018. An examination of the application period showed that the studies most commonly involved a period of 1 to 4 weeks $(37.8 \%)$. When the sample size was examined, 13 (28.9\%) studies were conducted with small samples while $9(20 \%)$ were with large samples. Finally, most studies were conducted in the field of Science with $26(26.8 \%)$ studies while the fewest studies were conducted in Social Sciences (4.4\%).

\section{Findings of Academic Success Studies Related to Impact Size}

Table 2 presents the mean effect size values of the studies included in the analysis. In this context, Table 2 shows that the Q-statistical value (404.324) was larger than the critical value (90.531). Therefore, it can be stated that the distribution was heterogeneous. Due to the heterogeneity of the distribution, in the calculation made using Random Effects Model (REM), the standard error was 0.091 and the upper limit of the $95 \%$ reliability interval was 0.748 . The lower limit was 0.389 , and the effect size value (ES) was found to be equal to 0.569 .

Table 2.

The Results of Studies' Effect Size Based on SEM and REM

\begin{tabular}{lccccccccc}
\hline \multirow{2}{*}{ Model Type } & \multirow{2}{*}{$\mathrm{n}$} & $\mathrm{Z}$ & $\mathrm{p}$ & $\mathrm{Q}$ & $\mathrm{d}$ & \multirow{2}{*}{$\mathrm{ES}$} & \multirow{2}{*}{$\mathrm{SE}$} & $\begin{array}{c}\text { \% 95 Confidence Interval } \\
\text { Lower Limit }\end{array}$ & Upper Limit \\
\hline SEM & 51 & 20.154 & 0.000 & 404.324 & 50 & 0.633 & 0.031 & 0.571 & 0.694 \\
REM & 51 & 6.219 & 0.000 & 68.511 & 50 & 0.569 & 0.091 & 0.389 & 0.748 \\
\hline
\end{tabular}

As can be seen from Table 2, ES $=0.569$ was evaluated according to the classification of effect size using the Thalheimer and Cook (2002) classification, and a medium effect size was found (0.40 - 0.75). Therefore, it was found that AR had a positive and moderate effect on academic success. Related to this, the effect size distribution graph of the studies included in the meta-analysis studies is given in Figure 2.

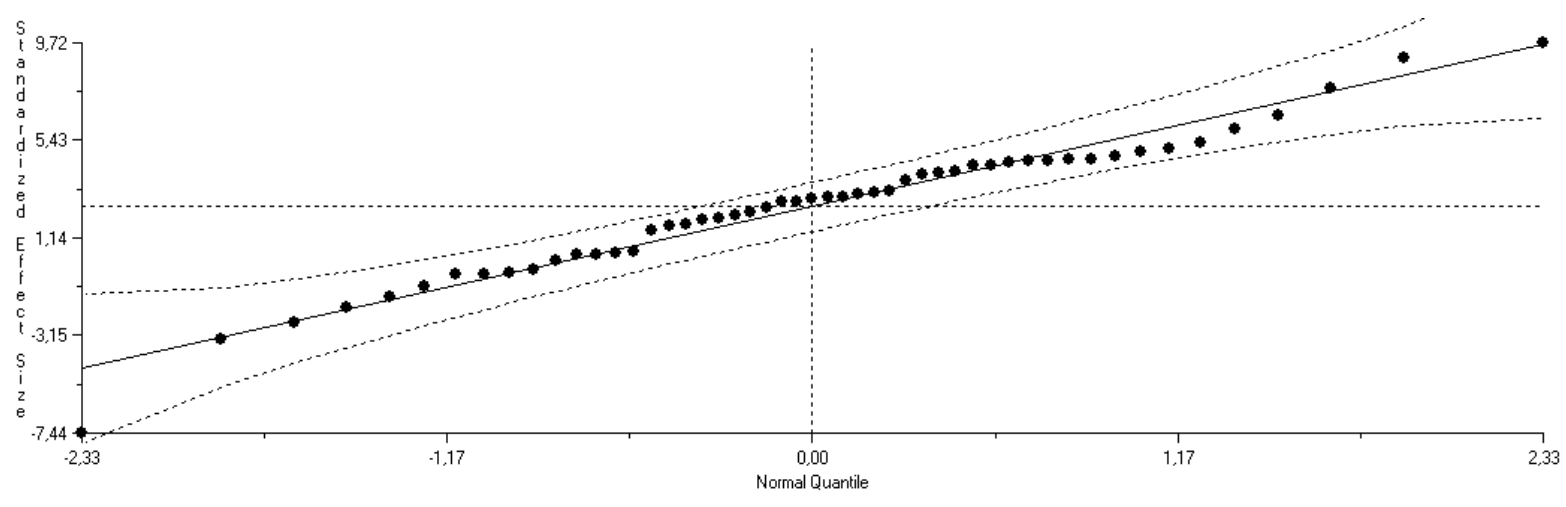

Figure 2. Normal Distribution Graph of Effect Sizes

In Figure 2, when the distribution of the effect sizes of the studies was considered, it can be seen that the distribution of the points was between two lines, and did not exceed the specified limits. Therefore, it can be stated that the distribution was in a reliable range, and therefore there is a statisticallysignificant relationship between studies. In this context, in meta-analysis studies, whether or not the effect size levels of the studies are within the scope of the analysis in terms of normal distribution, is related to the fact that the distribution was between two lines (Rosenberg, Adams \& Gurevitch, 2000). Another aspect of the reliability in terms of meta-analysis studies is the degree of publication bias. The inclusion of studies in a meta-analysis with only a significant difference in the literature may create publication bias. This situation needs to be eliminated or minimized. At this point, a value known as the fail-safe number (FSN) should be calculated (Rosenthal, 1979). For this study, an FSN value of 5993.4 was found for the effect of AR on academic success. It can be stated that if more studies with this value are included in the analysis, the significant effect may fall to zero. When the FSN value was compared 
with the number of studies included in the analysis, the FSN value was found to be quite high and unachievable. The interpretation of this finding reveals that publication bias has no impact on the significant effect size in the meta-analysis procedures in this study (Cheung \& Slavin, 2011). This result shows that the analyses were reliable.

\section{The Effect Sizes of Studies in Relation to Moderators}

From the results of the study, it can be seen that the level and the duration of the studies included in the analysis were different. For this reason, the aim was to examine whether or not the effect size values of the studies varied according to the education level and the duration of application. Table 3 presents the results of the moderator analysis according to the education level and the duration of the application related to the academic success included in the meta-analysis.

Table 3.

The Effect Sizes of Studies on Different Dimensions in Relation to Academic Success

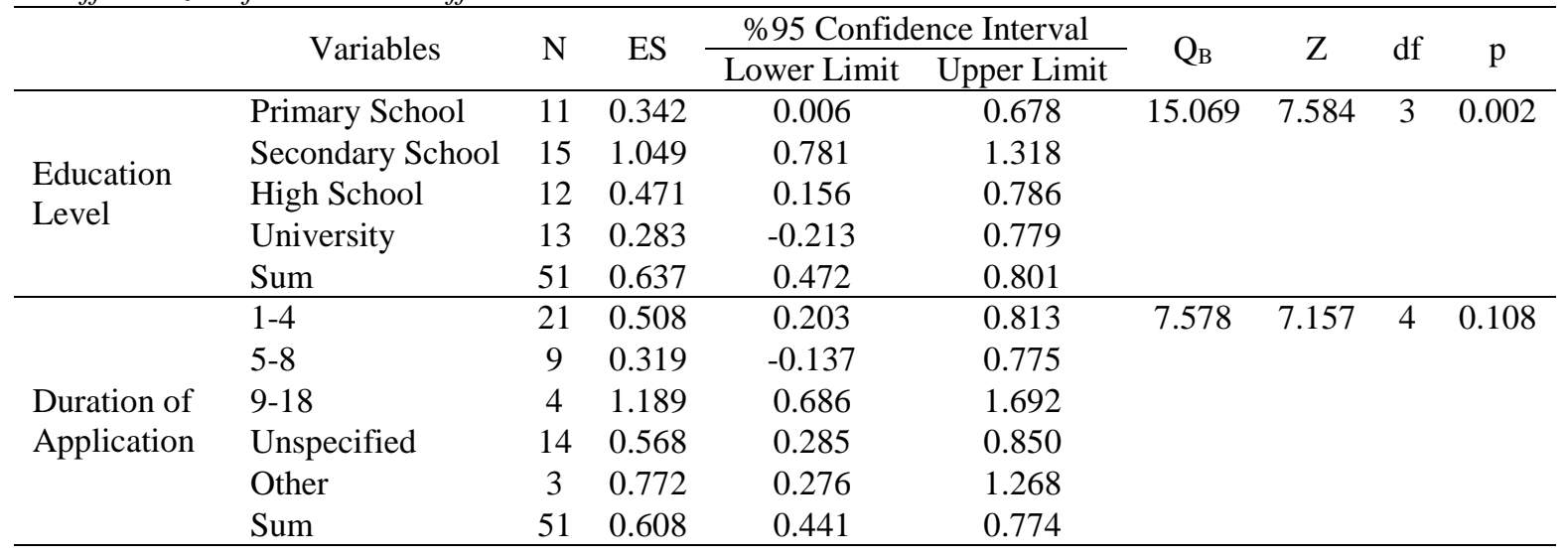

According to Table 3, when the homogeneity test between groups in terms of education level was examined, $\mathrm{QB}=15.069$ was found. In the $\chi 2$ table, $\chi 2$ was found to be $7.815(\chi 2(0.95)=7815)$ at the level of 95\% significance and 3 degrees of freedom. As the $\mathrm{QB}$ statistical value $(\mathrm{QB}=15.069)$ was bigger than the critical value of the $\chi^{2}$ distribution with 3 degrees of freedom $(\chi 2(0.95)=7.815$, it can be said that the distribution was heterogeneous. Accordingly, it can be stated that the overall effect size of the education levels $(\mathrm{ES}=0.637$ ) was moderate according to the classification proposed by Thalheimer and Cook (2002). Based on these results, it can be said that since the application of AR has a positive effect on academic success and involves significant differences $(\mathrm{p}=0.002)$, academic success varies depending on the education level under consideration.

Following the examination of the studies in terms of duration of application times, $\mathrm{QB}=7.578$ was found. The $\chi^{2}$ value was found to be $\chi^{2}=9.488$ with 4 degrees of freedom at a $95 \%$ significance level in table $\chi 2$. Therefore, it is understood that the QB statistical value is smaller than $\chi 2$. Consequently, the distribution of effect sizes was homogeneous, and the effect of AR on academic success does not change depending on the duration of use of the application ( $\mathrm{p}=0.108)$. Consequently, it can be said that the level of academic success is independent of the duration of use of the applications in the courses in which AR is used. On the other hand, the overall effect size value is $\mathrm{ES}=0.608$, indicating a moderate effect according to Thalheimer and Cook (2002). This finding may be interpreted as AR affecting academic success positively at a moderate level with regard to the length of use of the application.

\section{Findings about the Effectiveness of $A R$ in terms of Thematic Examination}

In this section of the study, the themes and codes that were obtained as a result of the meta-thematic work are used to support the meta-analytic findings and to provide enriched data for the study. Direct 
citations within the text were employed to support the thematic data which were presented in various forms and models. As a result of a detailed examination, thematic data were grouped under different themes in four models. The models which refer to the contributions of AR applications to the affective dimension and to the class environment, together with its limitations, are presented below.

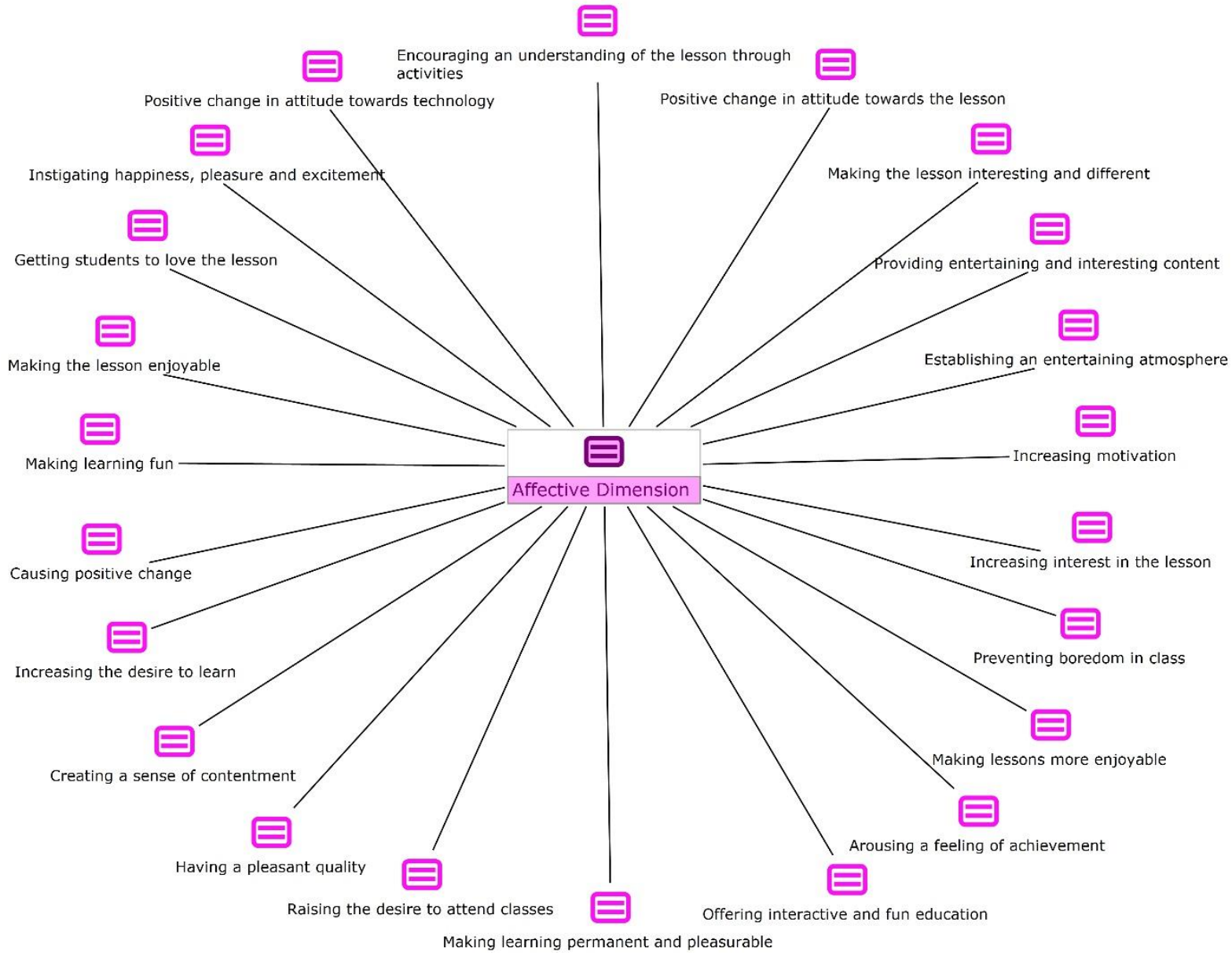

Figure 3. The Contributions of AR Applications to the Affective Dimension

In Figure 3, some of the codes that are mentioned in the context of the contribution of AR applications to the affective dimension can be summarized as changing the attitude positively, making lessons fun and, increasing learning desire and level of success.

In the context of this theme, expressions cited from the study coded 5-p.223, "The use of AR application in the course increased my willingness to learn. My interest in class has increased"; in the study coded 9-p.129 "I think it was more memorable and more fun. That's why I'm satisfied."; and in the study coded 15-p.52 "Providing interactive and entertaining education..." were identified as reference sentences and used in the formation of codes. The codes represent that learners take most advantage of AR applications as they feel more enjoyable during the lessons which result in their high desire to take part in the classes. 


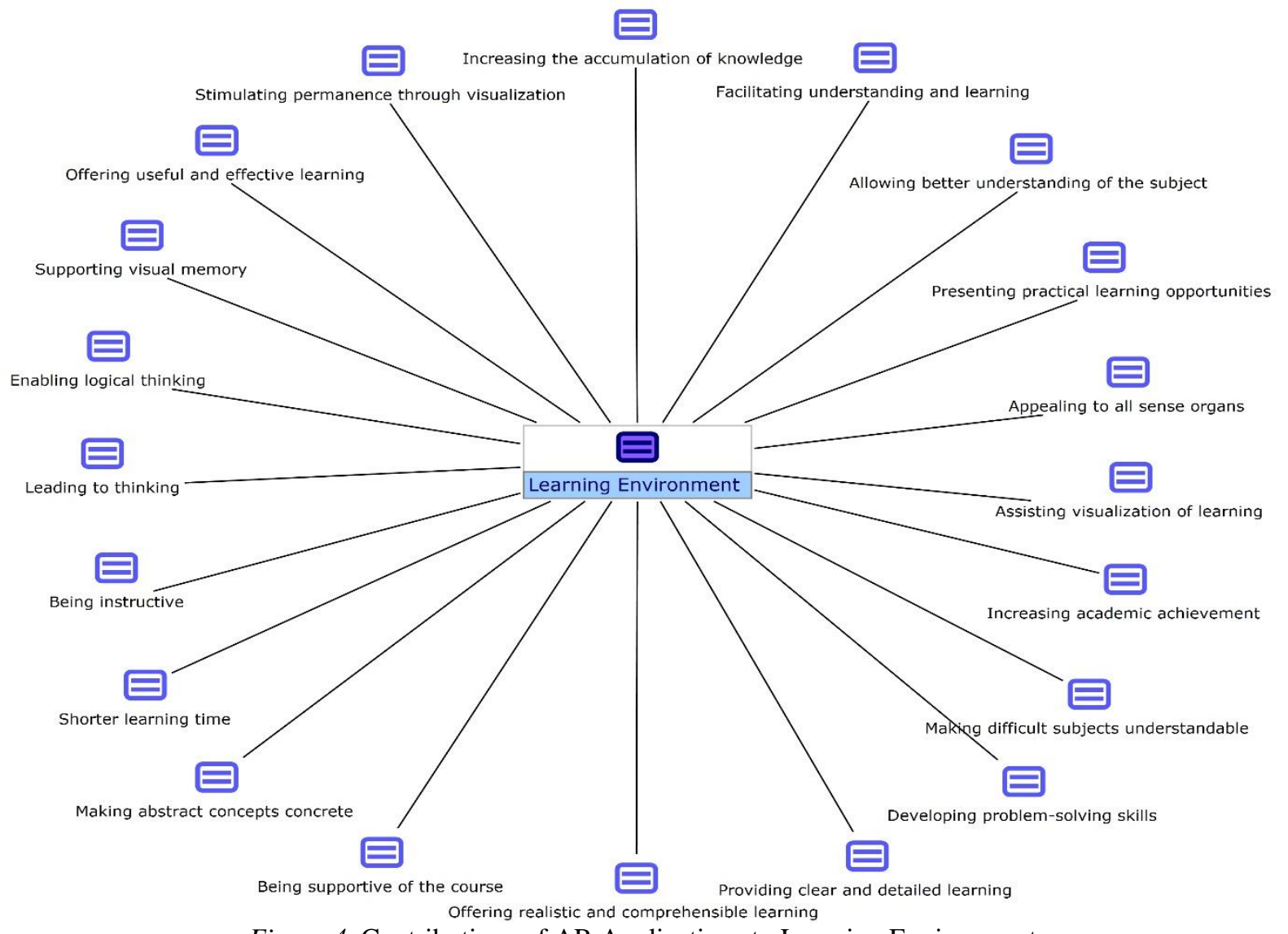

Figure 4. Contributions of AR Applications to Learning Environment

When Figure 4 is examined, it is understood from codes related to the contribution of AR applications to the learning environment in that making abstracts concrete, difficulties understandable, appealing to all senses, supporting visual and that sort of things.

Some of the expressions referred to in the creation of related codes include the one cited from the study coded 5-p.223 "...my interest in the lesson is increasing; the course is more fun and beautiful. I understand the subject better and I'm starting to love science more... I think it is effective in raising my exam grade in the science course."; or the one cited from the study coded 9-p.127 "Increases permanence. Supporting the course...". Also in the study coded 15-p.51 sentences such as "It is very important to have a source that appeals to all our senses in terms of effective learning and retention..." can be identified as basic sentences when creating the codes. Thus, as an effective tool used in the learning environment, AR is understood to relate learning process in such a way that it creates authentic, real, active, perceptible and concrete environments. 


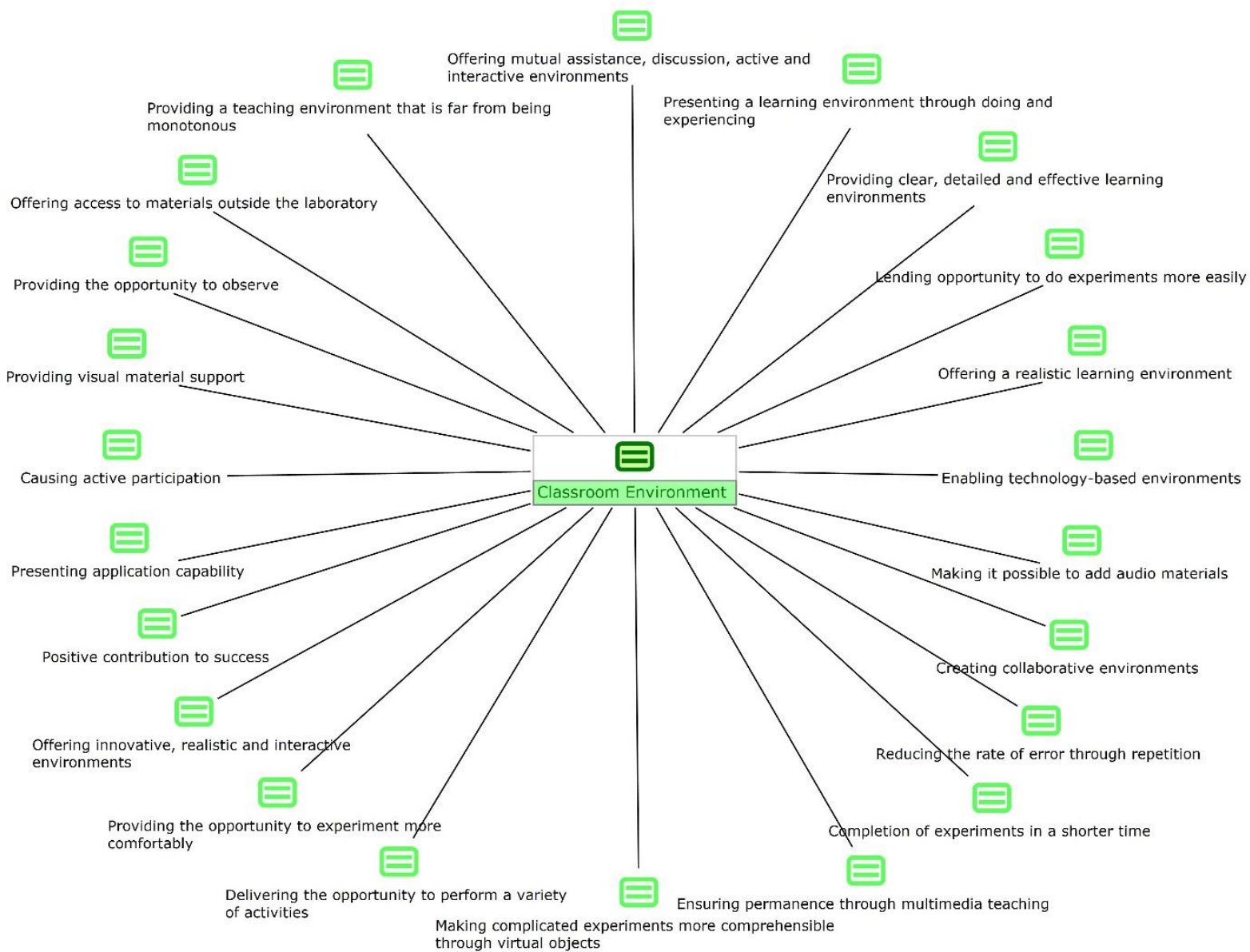

Figure 5. The Contributions of AR Applications to the Classroom Environment

Figure 5 shows the codes expressed in relation to the contributions of AR applications to the classroom environment. Some of these codes can presented as changing complexities in intelligibility, allowing experiments, offering a variety of activities, permanent and realistic learning, and a learning environment by doing.

Expressions that may refer to these codes and cited from the study coded 14-p.111 can be identified as "I learn better by doing activities in class. That's why it made me love science more. I liked it more because it was based on practice. It made lessons more fun." or cited from the study coded 5-p.231 "Thanks to the AR application, I took part in the science course more effectively, and I think my friends are also very active in the course. Some students in the classroom often sleep in class. But even they participated in the class. Doing the course with such interactive applications eliminated the boredom." The codes of the related theme seen in Figure 5 express the focus of digital information on classroom environment. Participants' interaction with the digital information and their knowledge acquisition via $\mathrm{AR}$ is considered to be evidences of its effectiveness in the classroom. 


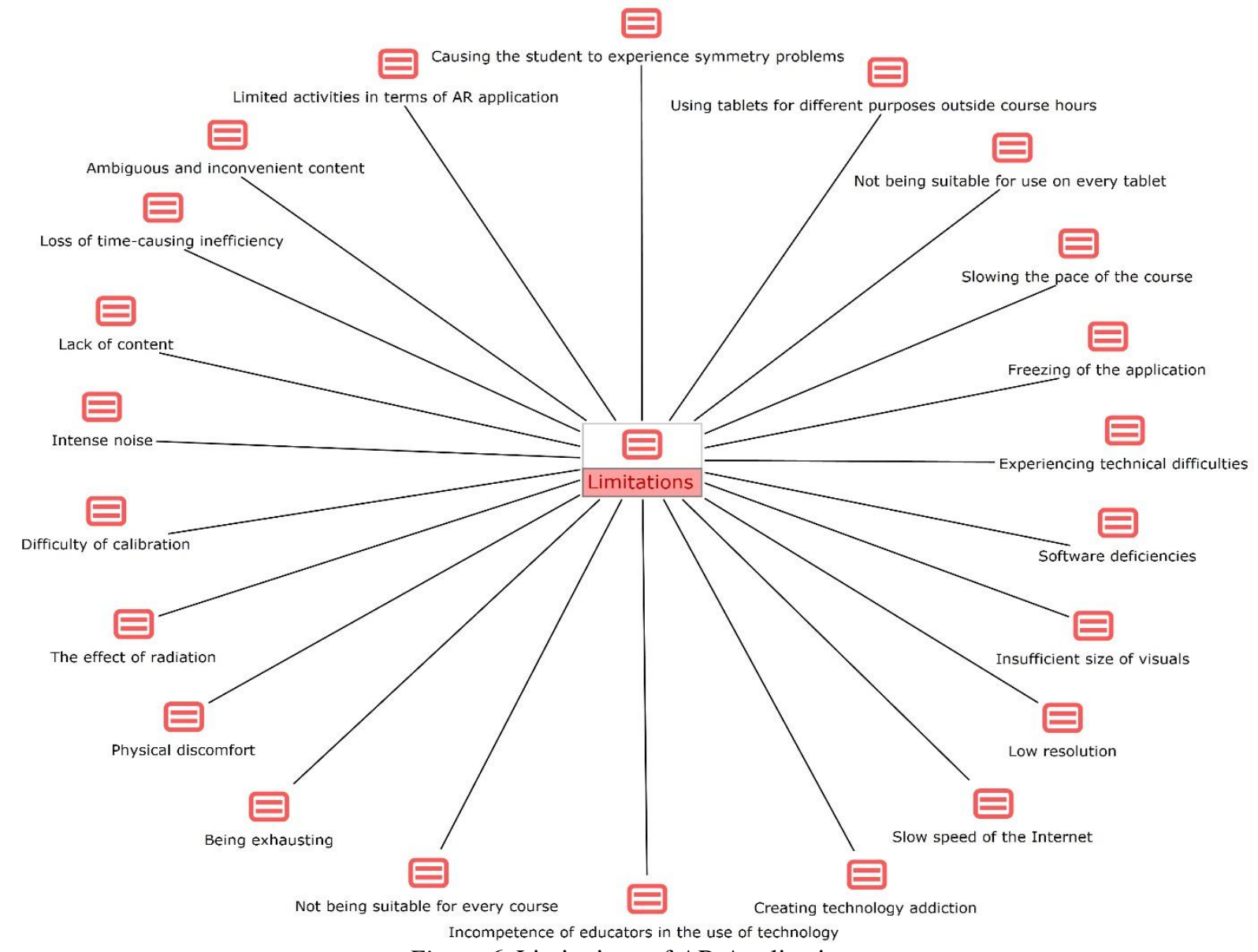

Figure 6. Limitations of AR Applications

When Figure 6 is examined, it can be seen that the limitations of the AR applications are also expressed. Some of the prominent codes can be remarked as physical discomfort, low resolution, educators' technology usage skills and technical deficiencies.

Related codes are formed based on the cited expressions such as "I had a painful and stiff neck once. My arm was numb. Continuously looking at tablets is harmful to our eyes... When I use tablets, it causes addiction; I always want to use it." (5-p.232); "It's difficult to calibrate. When I keep the shape perpendicular to the screen, it gets out of the angle of the camera and disappears. There is also a problem in the symmetry and it is a problem in the application." (11-p.71). Under the theme stated as limitations of AR, it is seen that there are some negative effects of AR on health, social and academic life etc. But if it is used in a more careful and planned way, there will be no problem in fact.

\section{DISCUSSION and CONCLUSION}

In this research, meta-analytic and thematic evaluations were made about the use of AR in educational environments which has the potential to bring the real world and the virtual world together. In this context, firstly, the data from the studies that were conducted in 2013-2019 and included in the metaanalysis were examined, and the studies were found to be generally conducted at the secondary and university levels in the form of article publications, and in the field of science. On the other hand, it was noted that the studies were mainly focused on the period between 2014 and 2018 inclusive, and were of 1 to 4 weeks duration, and were was conducted in terms of medium sized samples. On the other hand, 
as a result of the analysis done according to REM, it was determined that AR had a significantly moderate positive effect $(\mathrm{ES}=0.569)$ on academic success. In the studies conducted on the subject, AR applications have a positive impact on academic success and thus support the current research (Akçayır, 2018; Y1lmaz \& Batd1, 2016). The reasons why AR positively affects academic success can be stated as follows: it helps students better understand the subject by providing rich content, better retention and increased permanence in the long term memory. In addition, it develops students' motor skills, and improves the degree of cooperation among students (Radu, 2014). In addition, among the reasons for the increase in success through the use of AR applications is that they can also facilitate students' learning by increasing their motivation (Demirel, 2017), concretizing the subjects under consideration, eliminating misconceptions and providing permanence (Cai, Chiang \& Wang, 2013; Sirakaya, 2015). The related expressions above support the present result of the research.

To complete the meta-analysis results of the study, a thematic analysis was made, and various themes and codes related to the effects of AR on certain dimensions were formed. In terms of its contributions to the affective dimension, it was found that AR applications help associate the issues being considered in the classroom with real life situations, leading to an increase in motivation and a corresponding positive change in attitude towards the course and technology. The similar results can be found in the studies conducted in both national and international area (Delello, 2014; İbili \& Şahin, 2013; Kerawalla et al., 2006; Taşkıran et al., 2015; Yen et al., 2012). In addition, it was determined that AR applications made the students actively participate in the process by making the course interesting and different, by increasing their curiosity, and by making the learning process fun, active and effective. When the literature was reviewed it was reported in many studies that AR has many effects on students' active behaviors and positive attitudes toward lessons (Ibáñez, Di-Serio, Villaran-Molina \& Delgado-Kloos, 2016; Sirakaya, 2015). Moreover, it was concluded that AR can create an enjoyable atmosphere which makes learners relaxed and ready for the lesson. Moreover, it was stated that the educational and mental facilitation offered by AR increased the interest in the course and made the course popular by preventing boredom (Erbas \& Demirer, 2019; Fidan, 2018). These citations also can support the present study.

In terms of its contributions to the learning environment, it was understood that AR concretized the subject and made complicated issues more comprehensible through visualization of the invisible, and by providing abstract structures in three dimensions. The similar results were concluded in other studies also. They mentioned that AR makes subjects easy to learn and understand (Lee, 2012; Somyürek, 2014; Walczak et al., 2006; Wu et al., 2013). Moreover, AR facilitated understanding and learning, provided clear and detailed learning, provided for increased the understanding of difficult subjects, and offered useful and effective learning opportunities. Finally, AR applications, which occupy an important place in the active learning process, (Amo, Erkoyuncu, Roy, Palmarini \& Onoufriou, 2018; Baysan, 2015; Radu, 2014) offers more permanent learning by appealing to all the sense organs. This opportunity of AR help students remembers the things easily.

The view that AR can positively contribute to the classroom environment through teaching nonobservable subjects, reducing the rate of error with the opportunity for repetition, and providing innovative, realistic, collaborative and interactive environments, stands out in this study. In addition, it is suggested as another advantage of the use of applications is that it offers a more active and colorful learning environment which is far from monotonous, by providing opportunities to do a variety of activities (Fidan, 2018). Furthermore, it helps students to undertake experiments that are not easy to do in the real world, and assists educators to teach subjects that can be complicated and costly to explain, and make them clearer (Baysan, 2015; Erbas \& Demirer, 2019; Küçük, 2015). In addition, the AR applications were recorded to encourage active learner engagement and enable educators to create educational environments in which learners are at the center of the learning process and learn by doing and experiencing. These contributions all affect the classroom atmosphere positively and create an interactive learning environment.

In addition to the contributions of AR applications to education and other fields, their limitations should also be noted. In particular, insufficient hardware, low internet speeds, late detection of the object on 
the application by the camera, and occasional freezing are some of the leading limitations associated with the use of AR (Çömen, 2018; Küçük, 2015; Şentürk, 2018). In addition, when AR is used, some technical problems may be experienced including problems caused by external factors such as ambient light, poor output and image quality, or too much charge consumption (Akkuş, 2016; Çömen, 2018; Şentürk, 2018). Another limitation observed in the study relates to webcam and monitor calibration problems during the use of applications (Akkuş, 2016). In location-based mobile AR applications, GPS detection problems and problematic use in enclosed settings (Pérez-Sanagustín, Hernández-Leo, Santos, Kloos \& Blat, 2014), and students' loss of focus on the subject due to not being used to coping with education outside the classroom environment (Chiang, Yang \& Hwang, 2014), could be observed. Another result of this study is a lack of content in terms of AR applications, time-consuming content development, and lack of comprehensibility and usability of content (Küçük, 2015). Educators and learners who believe that they will have difficulty in overcoming such limitations may be unwilling to enter the AR environment (Akkuş, 2016; Yuen et al., 2011). Therefore, it is necessary to eliminate these negative aspects in order to effectively implement the use of AR in education. As stated before, AR technology can create new opportunities in education to promote learning and create constructivist learning environments (Huang, Chen \& Chou, 2016). In this respect, it is of utmost importance that students have access to technological tools and resources at the appropriate level. In addition, technical problems during the use of applications must be eliminated, and for this purpose increased time and more skilled labor is required. In order to avoid any problems during the use of applications, it is recommended that usability tests be carried out and that necessary precautions are taken, such as ensuring that lighting is sufficient in the environment in which AR applications are to be used. Finally, it is recommended that students be provided with technical support before and during the use of the application.

\section{Limitations}

For this research, some limitations can be noted. It included AR applications for academic success, learning environment and affective dimensions. Some other variations like social and individual skills, self/peer-assessment, motivation, etc. can be examined in detail. The included studies and inclusion criteria can be expanded. In addition, in meta-analysis process, the number of moderators can be increased.

\section{REFERENCES}

*(References with an asterisk (*) indicate studies included in the meta-analysis.)

*Abdüsselam, M. S., \& Karal, H. (2012). The effect of mixed reality environments on the students' academic achievement in physics education: 11th grade magnetism topic example. Journal of Research in Education and Teaching, 1(4), 170-181.

Akbaş, M. F., \& Güngör, C. (2017). A survey on marker-based tracking systems in augmented reality and design of multi-layer marker model. Dokuz Eylul University-Faculty of Engineering Journal of Science and Engineering, 19(56), 599-619.

*Akçayır, M. (2016). The effect of augmented reality applications on university students' laboratory skills, attitudes and task loads. (Unpublished doctoral dissertation), Gazi University, Ankara.

Akçayır, G. (2018). The effect of augmented reality in education: A meta-analysis and systematic literature review. (Unpublished doctoral dissertation), Gazi University, Ankara.

*Akkuş, İ. (2016). Effects of augmented reality applications on mechanical engineering freshmen's level of academic achievement and spatial ability in computer aided technical drawing. (Unpublished master's dissertation), Inonu University, Malatya.

Alcañiz, M., Contero, M., Perez-Lopez, D. C., \& Ortega, M. (2010). Augmented reality technology for education. In New Achievements in Technology, Education and Development. Edited by S. Soomro. New York: IntechOpen, 247-256. 
Amo, I. F., Erkoyuncu, J. A., Roy, R., Palmarini, R., \& Onoufriou, D. (2018). A systematic review of augmented reality content-related techniques for knowledge transfer in maintenance applications. Computers in Industry, 103, 47-71. DOI: 10.1016/j.compind.2018.08.007.

Azuma, R. T. (1997). A survey of augmented reality. Presence: Teleoperators and Virtual Environments, 6(4), $355-385$.

Azuma, R. T. (1999). The challenge of making augmented reality work outdoors. Mixed Reality: Merging Real and Virtual Worlds, Yuichi Ohta and Hideyuki Tamura (ed.) 379-390.

*Babur, A. (2016). The effects of using of augmented reality, simulation and real object on learning achievements, motivation and psychomotor performance. (Unpublished doctoral dissertation), Sakarya University, Sakarya.

*Bal, E., \& Bicen, H. (2016). Computer hardware course application through augmented reality and QR code integration: Achievement levels and views of students. Procedia Computer Science, 102, 267-272.

Barsom, E. Z., Graafland, M., \& Schijven, M. P. (2016). Systematic review on the effectiveness of augmented reality applications in medical training. Surgical Endoscopy, 30(10), 4174-4183. DOI: 10.1007/s00464016-4800-6.

Batd1, V. (2017). The effect of multiple intelligences on academic achievement: A meta-analytic and thematic study. Educational Sciences: Theory \& Practice, 17, 2057-2092. DOI:10.12738/estp.2017.6.0104

Batd1, V., \& Batd1, H. (2015). Effect of creative drama on academic achievement: A meta-analytic and thematic analysis. Educational Sciences: Theory and Practice, 15(6), 1459-1470. DOI:10.12738/estp.2015.6.0156

*Baysan, E. (2015). The impact of augmented reality book (AR-Book) usage on the students' academic achievements and students' reviews on it. (Unpublished master's dissertation), Gazi University, Ankara.

Bernard, R. M., Abrami, P. C., Lou, Y., Borokhovski, E., Wade, A., Wozney, L., ... \& Huang, B. (2004). How does distance education compare with classroom instruction? A meta-analysis of the empirical literature. Review of Educational Research, 74(3), 379-439.

Billinghurst, M., \& Dunser, A. (2012). Augmented reality in the classroom. Computer, 45(7), 56-63.

*Bursali, H., \& Yilmaz, R. M. (2019). Effect of augmented reality applications on secondary school students' reading comprehension and learning permanency. Computers in Human Behavior, 95, 126-135.

*Cai, S., Chiang, F. K., \& Wang, X. (2013). Using the augmented reality 3D technique for a convex imaging experiment in a physics course. International Journal of Engineering Education, 29(4), 856-865.

Cardos, R. A. I, David, O. A., \& David, D. O. (2017). Virtual reality exposure therapy in flight anxiety: A quantitative meta-analysis. Computers in Human Behavior, 72, 371-380.

*Chang, R. C., Chung, L. Y., \& Huang, Y. M. (2016). Developing an interactive augmented reality system as a complement to plant education and comparing its effectiveness with video learning. Interactive Learning Environments, 24(6), 1245-1264.

*Chang, Y. H. (2013). Applying an AR technique to enhance situated heritage learning in a ubiquitous learning environment. Turkish Online Journal of Educational Technology-TOJET, 12(3), 21-32.

*Chen, C. H., Huang, C. Y., \& Chou, Y. Y. (2019). Effects of augmented reality-based multidimensional concept maps on students' learning achievement, motivation and acceptance. Universal Access in the Information Society, 18(2), 257-268.

*Chen, C. M., \& Tsai, Y. N. (2012). Interactive augmented reality system for enhancing library instruction in elementary schools. Computers \& Education, 59(2), 638-652.

Chen, C. P., \& Wang, C. H. (2015). Employing augmented-reality-embedded instruction to disperse the imparities of individual differences in earth science learning. Journal of Science Education and Technology, 24(6), 835-847.

Cheng, K. H., \& Tsai, C. C. (2013). Affordances of augmented reality in science learning: Suggestions for future research. Journal of Science Education and Technology, 22(4), 449-462.

Cheung, A. C. K., \& Slavin, R. E. (2011). The effectiveness of educational technology applications for enhancing mathematics achievement in K-12 classrooms: A metaanalysis. Educational Research Review, 9, 88-113. DOI: 10.1016/j.edurev.2013.01.001.

*Chiang, T. H. C., Yang, S. J., \& Hwang, G. J. (2014). An augmented reality-based mobile learning system to improve students' learning achievements and motivations in natural science inquiry activities. Educational Technology \& Society, 17(4), 352-365.

*Chien, Y. C., Su, Y. N., Wu, T. T., \& Huang, Y. M. (2019). Enhancing students' botanical learning by using augmented reality. Universal Access in the Information Society, 18(2), 231-241.

*Civelek, T., Ucar, E., Ustunel, H., \& Aydin, M. K. (2014). Effects of a haptic augmented simulation on K-12 students' achievement and their attitudes towards Physics. Eurasia Journal of Mathematics, Science \& Technology Education, 10(6), 565-574.

*Coşkun, M. (2018). The impact of the teaching supported with mobile application and augmented reality on motivation and anxiety about Science lesson, attitude towards Astronomy, and academic success of students. (Unpublished master's dissertation), Mustafa Kemal University, Hatay. 
*Cubillo, J., Martin, S., Castro, M., \& Boticki, I. (2015). Preparing augmented reality learning content should be easy: UNED ARLE - an authoring tool for augmented reality learning environments. Computer Applications in Engineering Education, 23(5), 778-789.

*Çömen, H. (2018). Investigation of a hybrid design book based on the writing to learn activities supported learning environment in the seventh-grade electrical energy unit. (Unpublished master's dissertation), Uşak University, Uşak.

Delello, J. A. (2014). Insights from pre-service teachers using science-based augmented reality. Journal of Computers in Education, 1(4), 295-311.

*Demirel, T. (2017). The effect of augmented reality activities supported by argumentation approach on academic achievement, critical thinking skills, motivation towards science and technology course and argumentation skills. (Unpublished doctoral dissertation), Çukurova University, Adana.

*Doğan, Ö. (2016). The effectiveness of augmented reality supported materials on vocabulary learning and retention. (Unpublished master's dissertation), Abant Izzet Baysal University, Bolu.

Dunleavy, M., \& Dede, C. (2014). Augmented reality teaching and learning. In J. M. Spector, M. D. Merrill, J. Elen and M. J. Bishop (Eds.), The handbook of research for educational communications and technology, (4th ed.). New York: Springer.

Dunleavy, M., Dede, C., \& Mitchell, R. (2009). Affordances and limitations of immersive participatory augmented reality simulations for teaching and learning. Journal of Science Education and Technology, 18(1), 7-22, DOI: $10.1007 / \mathrm{s} 10956-008-9119-1$

*Erbas C, Demirer V. (2019). The effects of augmented reality on students' academic achievement and motivation in a Biology course. Journal of Computer Assisted Learning, 35, 450-458. DOI: 10.1111/jcal.12350.

*Ersoy H., Duman E., \& Öncü S. (2016). Motivation and success with augmented reality: An experimental study. Journal of Instructional Technologies \& Teacher Education, 5(1), 39-44.

Erwin, E.J., Brotherson, M.J., \& Summers, J.A. (2011). Understanding qualitative meta synthesis: issues and opportunities in early childhood intervention research. Journal of Early Intervention, 33(3), 186-200.

*Fidan, M., (2018). The impact of problem-based science teaching assisted with augmented reality applications on academic achievement, retention, attitude and belief of self-efficacy. (Unpublished doctoral dissertation), Abant Izzet Baysal University, Bolu.

Fleck, S., Simon, G., \& Christian Bastien, J. M. (September, 2014). AIBLE: An inquiry-based augmented reality environment for teaching astronomical phenomena. 2014 IEEE International Symposium on Mixed and Augmented Reality - Media, Art, Social Science, Humanities and Design, Münich, Germany.

*Gopalan, V. (2016). Conventional approach vs augmented reality textbook on learning performance: A study in science learning among secondary school students. Revista de la Facultad de Ingeniería, 31(5), 19-26.

Graham M., Zook M., \& Boulton A. (2013). Augmented reality in urban places: Contested content and the duplicity of code. Transactions of the Institute of British Geographers. 38(3), 464-479. DOI: 10.1111/j.1475-5661.2012.00539.x.

Hedges, L. V. \& Olkin, I. (1985). Statistical methods for meta-analysis. Orlando, FL: Academic Press.

*Ibáñez, M. B., Di-Serio, A., Villaran-Molina, D., \& Delgado-Kloos, C. (2014). Experimenting with electromagnetism using augmented reality: Impact on flow student experience and educational effectiveness. Computers \& Education, 71, 1-13.

Huang, T. C., Chen, C. C., \& Chou, Y. W. (2016). Animating eco-education: To see, feel, and discover in an augmented reality-based experiential learning environment. Computers \& Education, 96, 72-82.

*Ibáñez, M. B., Di-Serio, A., Villaran-Molina, D., \& Delgado-Kloos, C. (2016). Support for augmented reality simulation systems: the effects of scaffolding on learning outcomes and behavior patterns. IEEE Transactions on Learning Technologies, 9(1), 46-56.

Ivanova, M., \& Ivanov, G. (2011). Enhancement of learning and teaching in computer graphics through marker augmented reality technology. International Journal on New Computer Architectures and their Applications, 1(1), 176-184.

İbili, E., \& Şahin, S. (2013). Software design and development of an interactive 3D Geometry book using augmented reality: ARGE3D. Afyon Kocatepe University Journal of Science and Engineering, 13(1), 18. DOI: $10.5578 / \mathrm{fmbd} .6213$.

*Jee, H. K., Lim, S., Youn, J., \& Lee, J. (2014). An augmented reality-based authoring tool for e-learning applications. Multimedia Tools and Applications, 68(2), 225-235.

Kamphuis, C., Barsom, E., Schijven, M., \& Christoph, N. (2014). Augmented reality in medical education? Perspectives on Medical Education, 4(1), 300-311.

*Karagozlu, D. (2018). Determination of the impact of augmented reality application on the success and problemsolving skills of students. Quality \& Quantity, 52(5), 2393-2402.

Kerawalla, L., Luckin, R., Seljeflot, S., \& Woolard, A. (2006). Making it real: Exploring the potential of augmented reality for teaching primary school science. Virtual Reality, 10(3-4), 163-174. 
*Kose, U., Koc, D., \& Yucesoy, S. A. (2013). An augmented reality based mobile software to support learning experiences in computer science courses. Procedia Computer Science, 25, 370-374.

*Küçük, S. (2015). Effects of learning anatomy via mobile augmented reality on medical students' academic achievement, cognitive load, and views toward implementation. (Unpublished doctoral dissertation), Atatürk University, Erzurum.

Lee, K. (2012). Augmented reality in education and training. TechTrends, 56(2), 13-21.

Lehner, O. M., \& Kaniskas, J. (2012). Opportunity recognition in social entrepreneurship: A thematic metaanalysis. The Journal of Entrepreneurship, 21(1), 25-58.

*Lin, H. C. K., Chen, M. C., \& Chang, C. K. (2015). Assessing the effectiveness of learning solid geometry by using an augmented reality-assisted learning system. Interactive Learning Environments, 23(6), 799-810.

Lin, H. C. K., Hsieh, M. C., Wang, C. H., Sie, Z. Y., \& Chang, S. H. (2011). Establishment and usability evaluation of an interactive AR learning system on conservation of fish. Turkish Online Journal of Educational Technology-TOJET, 10(4), 181-187.

*Lin, T. J., Duh, H. B. L., Li, N., Wang, H. Y., \& Tsai, C. C. (2013). An investigation of learners' collaborative knowledge construction performances and behavior patterns in an augmented reality simulation system. Computers \& Education, 68, 314-321.

Liu, C., Cao, S., Tse, W., \& Xu, X. (2017). Augmented reality-assisted intelligent window for cyber-physical machine tools. International Journal of Industrial and Manufacturing Systems Engineering, 44, 280-286. DOI: $10.1016 /$ j.jmsy.2017.04.008.

Miles, M. B., \& Huberman, A. M. (1994). Qualitative data analysis: An expanded sourcebook. Thousand Oaks, California: Sage.

Moher, D., Liberati, A., Tetzlaff, J., Altman, D. G., \& Prisma Group. (2009). Preferred reporting items for systematic reviews and meta-analyses: the PRISMA statement. PLoS Medicine, 6(7), e1000097.

Özarslan, Y. (2013). The effect of augmented reality enhanced learning materials on learners' achievement and learners' satisfaction. (Unpublished doctoral dissertation), Anadolu University, Eskişehir.

*Özbek, F. (2018). Effect of the augmented reality in the elementary school 4th grade Turkish course on the achievement and motivation of the students. (Unpublished master's dissertation), Adnan Menderes University, Aydin.

Pérez-Sanagustín, M., Hernández-Leo, D., Santos, P., Kloos, C. D., \& Blat, J. (2014). Augmenting reality and formality of informal and non-formal settings to enhance blended learning. IEEE Transactions on Learning Technologies, 7(2), 118-131.

Phillips, W., Lee, H., Ghobadian, A., O’Regan, N., \& James, P. (2015). Social innovation and social entrepreneurship: a systematic review. Group \& Organization Management, 40(3), 428-461 DOI: $10.1177 / 1059601114560063$.

Rabbi, I., \& Ullah, S. (2013). A survey on augmented reality challenges and tracking. Acta Graphica, 24(1-2), 2946.

Radu, I. (2014). Augmented reality in education: A meta-review and cross-media analysis. Personal and Ubiquitous Computing, 18, 1533-1543.

Rauh, S., Zsebedits, D., Tamplon, E., Bolch, S., \& Meixner, G. (2015, September). Using Google Glass for mobile maintenance and calibration tasks in the AUDI A8 production line. In 2015 IEEE 20th Conference on Emerging Technologies \& Factory Automation (ETFA) (pp. 1-4). IEEE, Luxembourg.

*Renner, J. C. (2014). Does augmented reality affect high school students' learning outcomes in Chemistry? (Unpublished doctoral dissertation), Grand Canyon University, Phoenix, Arizona.

Rosenberg, M., Adams, D., \& Gurevitch, J. (2000). MetaWin statistical software for meta-analysis version 2.0, Massachusetts, MA: Sinauer Associates Inc.

Rosenthal, R. (1979). The file drawer problem and tolerance for null results. Psychological Bulletin, 86(3), 638 641.

Serino, M., Cordrey, K., McLaughlin, L., \& Milanaik, R. L. (2016). Pokémon Go and augmented virtual reality games: a cautionary commentary for parents and pediatricians. Current Opinion in Pediatrics, 28(5), 673677.

Schrier, K. (2006, July). Using augmented reality games to teach 21st century skills. In ACM SIGGRAPH 2006 Educators program (pp. 15-23). Boston: ACM Press. DOI: 10.1145/1179295.1179311.

*Sirakaya, M., (2015). Effects of augmented reality applications on students' achievement, misconceptions and course engagement. (Unpublished doctoral dissertation), Gazi University, Ankara.

*Solak, E., \& Cakir, R. (2016). Investigating the role of augmented reality technology in the language classroom. Online Submission, 18(4), 1067-1085.

*Sommerauer, P., \& Müller, O. (2014). Augmented reality in informal learning environments: A field experiment in a mathematics exhibition. Computers \& Education, 79, 59-68.

Somyürek, S. (2014). Gaining the attention of generation $\mathrm{Z}$ in learning process: Augmented reality. Educational Technology Theory and Practice, 4(1), 63-80. 
*Şahin, D. (2017). Effect of science teaching with the augmented reality technology on secondary school students' achievement and their attitude towards the course. (Unpublished master's dissertation), Atatürk University, Erzurum.

*Şentürk, M. (2018). The investigation with Solomon four-group design on the effect of using mobile augmented reality $(A R)$ applications in the unit titled solar system and beyond in the seventh-grade on the students' academic success, motivation, science and technology attitude. (Unpublished master's dissertation), Kocaeli University, Kocaeli.

*Tarng, W., Ou, K. L., Yu, C. S., Liou, F. L., \& Liou, H. H. (2015). Development of a virtual butterfly ecological system based on augmented reality and mobile learning technologies. Virtual Reality, 19(3-4), 253-266.

Taşkıran, A., Koral, E., \& Bozkurt, A. (2015). Artırılmış gerçeklik uygulamasının yabancı dil eğitiminde kullanılması [Using augmented reality in foreign language education]. In Akademik Bilisim, Eskisehir, Turkey.

Tekerdere, H. \& Göker, H. (2016). Examining the effectiveness of augmented reality applications in education: A meta-analysis. International Journal of Environmental \& Science Education, 11(16), 9469-9481.

Thalheimer, W., \& Cook, S. (2002). How to calculate effect sizes from published research: A simplified methodology. $\quad$ Work-Learning http://education.gsu.edu/coshima/EPRS8530/Effect_Sizes_pdf4.pdf.

Van Krevelen, D. W. F., \& Poelman, R. (2010). Augmented reality: Technologies, applications and limitations. International Journal of Virtual Reality, 9(2), 1-20.

Weber, R. (1990). Basis content analysis (2nd ed.). Thousand Oaks, CA: Sage Publications.

Viera, A. J. \& Garrett, J. M. (2005). Understanding interobserver agreement: The kappa statistic. Family Medicine, 37(5), 360-363.

Walczak, K., Wojciechowski, R., \& Cellary, W. (2006, November). Dynamic interactive VR network services for education. In Proceedings of the ACM symposium on virtual reality software and technology (pp. 277286). (VRST'06). New York: ACM. DOI: 10.1145/1180495.1180552.

Wojciechowski, R., \& Cellary, W. (2013). Evaluation of learners' attitude toward learning in ARIES augmented reality environments. Computers \& Education, 68, 570-585.

Wu, H. K., Lee, S. W. Y., Chang, H. Y., \& Liang, J. C. (2013). Current status, opportunities and challenges of augmented reality in education. Computers \&Education, 62, 41-49.

*Wu, P. H., Hwang, G. J., Yang, M. L., \& Chen, C. H. (2018). Impacts of integrating the repertory grid into an augmented reality-based learning design on students' learning achievements, cognitive load and degree of satisfaction. Interactive Learning Environments, 26(2), 221-234.

*Yang, M. T., \& Liao, W. C. (2014). Computer-assisted culture learning in an online augmented reality environment based on free-hand gesture interaction. IEEE Transactions on Learning Technologies, 7(2), 107-117.

*Yao, S. (2018). Teaching structural analysis with a mobile augmented reality application. (Unpublished master's dissertation), Iowa State University, Ames, Iowa.

Yen J. C., Tsai C. H., \& Wang J. Y. (2012). The effects of augmented reality on students' moon phases concept learning and their conceptual changes of misconception. International Conference on Business and Information, Sapporo, Japan.

*Y1ldırım, P. (2018). The impact of science teaching made with mobile augmented reality technology on science and technology attitudes and academic achievement of secondary school students. (Unpublished master's dissertation), Firat University, Elazı̆̆.

Yıldırım, A., \& Şimşek, H. (2013). Sosyal bilimlerde nitel araştırma Yöntemleri [Qualitative research methods in the social sciences], Seckin Publishing, Ankara, Turkey.

Yilmaz, Z. A., \& Batdi, V. (2016). A meta-analytic and thematic comparative analysis of the integration of augmented reality applications into education. Education and Science, 41(188), 273-289.

Yuen, S., Yaoyuneyong, G., \& Johnson, E. (2011). Augmented reality: An overview and five directions for AR in education. Journal of Educational Technology Development and Exchange, 4(1), 119-140 


\section{APPENDIX 1.}

\section{Cohen Kappa Values of Themes in the Study}

\begin{tabular}{|c|c|c|c|c|c|c|c|c|c|c|c|c|c|c|c|c|}
\hline & \multicolumn{4}{|c|}{$\begin{array}{c}\text { Affective } \\
\text { Dimension }\end{array}$} & \multicolumn{4}{|c|}{ Learning } & \multicolumn{4}{|c|}{ Classroom } & \multicolumn{4}{|c|}{ Limitations } \\
\hline \multicolumn{5}{|c|}{$\mathrm{K} 2$} & \multicolumn{4}{|c|}{$\mathrm{K} 2$} & \multicolumn{4}{|c|}{$\mathrm{K} 2$} & \multicolumn{4}{|c|}{$\mathrm{K} 2$} \\
\hline \multirow{4}{*}{$\bar{\nabla}$} & & + & - & $\Sigma$ & \multirow{3}{*}{$\vec{\nabla}$} & + & - & $\Sigma$ & \multirow{3}{*}{$\vec{\nabla}$} & + & - & $\Sigma$ & \multirow{3}{*}{$\nabla$} & + & - & $\Sigma$ \\
\hline & + & 22 & 3 & 25 & & 20 & 3 & 23 & & 22 & 2 & 24 & & 22 & 2 & 24 \\
\hline & - & 4 & 19 & 23 & & 2 & 16 & 18 & & 1 & 19 & 20 & & - & 14 & 16 \\
\hline & $\Sigma$ & 26 & 22 & 48 & & 22 & 19 & 41 & & 23 & 21 & 44 & & 24 & 16 & 40 \\
\hline $\mathrm{Ka}$ & pa: . & 707 & & 000 & $\mathrm{Ka}$ & pa: .754 & & 00 & & pa: .863 & & 000 & & pa:.792 & $\mathrm{p}:$ & 00 \\
\hline
\end{tabular}




\section{TÜRKÇE GENIŞLETILMIŞ ÖZET}

Gerçek ve sanal dünyayı bir araya getirmenin yanı sıra etkileşimli ortamlardan oluşması özelliğiyle son yıllarda eğitim araştırmacılarının dikkatini çeken artırılmış gerçeklik (AG), eğitim ortamlarında hızla yer edinmeye başlamıştır. Özellikle akıllı telefon ve tablet bilgisayarlarda yaşanan hızlı gelişmeler AG uygulamasını laboratuvar ortamından çıkarak akıllı cihazlarda çalışan ve ulaşılması kolay uygulamalara dönüştürmüştür. AG uygulamasının gerçek dünyada ulaşılamayan, somutlaştırılamayan veya yüksek maliyet nedeniyle gerçekleştirilemeyen birçok deneyi ve konuyu basılı kaynaklar ve mobil cihazlarla etkileşimli olarak bir arada kullanmaya imkân veren yapısı göz önüne alındığında AG teknolojisinin eğitimde etkili kullanımına katkı sağlayabileceği düşünülmektedir.

AG uygulamalarının eğitim ortamlarında etkililiği, uygulamanın avantajları, uygulama sırasında karşılaşılan problemleri ve zorlukları inceleyen kapsamlı ve ayrıntılı araştırmaların yapılması ve sonuçlarının değerlendirilmesi gerekmektedir. Bu nedenle AG'nin eğitim alanındaki etkililiğinin kapsamlı ve bütüncül bir bakış açısıyla irdelenerek başarıyla olan ilişki düzeyinin her yönüyle ortaya konulması için detaylı bir analize gerek duyulmuştur. Bu araştırmalardan elde edilecek veriler, AG teknolojisini kullanmak isteyen eğitimcilere gerekli bilgileri sağlamakla birlikte ileride gerçekleştirilecek çalışmalara yol gösterici nitelikte olacağı düşünülmektedir. Bu bağlamda araştırmanın asıl amacı, AG’nin eğitimde kullanımı konusunda gerçekleştirilmiş çalışmaları bütüncül bir yaklaşımla incelemektir.

Araştırmada eğitimde AG kullanımının etkililiğini belirlemek amacıyla meta-analiz yöntemi kullanılmıştır. Veri toplama sürecinde öncelikle akademik başarı boyutunda AG ile ilgili yapılmış çalışmalara ulaşmak ve incelemek amacıyla veri tabanları ve arama ölçütleri belirlenmiştir. Veri toplama sürecinin sonunda, meta-analize dâhil edilme ölçütlerine uygun olan ve etki büyüklüğü hesaplaması için gerekli ve yeterli bilgileri içeren 18 'i tez, 27 'si makale olmak üzere toplamda 45 çalışmaya ait etki büyüklüğü analiz edilmiştir.

Çalışmada ayrıca araştırmanın iç geçerliliğine katkı sağlamak amacıyla nitel çalışmalar taranarak metatematik analizler de yapılmıştır. Bu doğrultuda alanyazında AG konusuyla ilgili nitel çalışmalar taranmış ve yapılan taramada 19 çalışmaya ulaşılmıştır. Araştırmanın nitel verileri, MAXQDA nitel veri analiz programı kullanılarak içerik analizi yöntemiyle çözümlenmiştir.

REM'e göre yapılan analiz sonucunda AG'nin akademik başarı üzerinde pozitif yönde ve orta düzeyde anlamlı bir etkisinin olduğu tespit edilmiştir. Konuyla ilgili yapılan çalışmalarda da, AG uygulamasının akademik başarıyı olumlu etkilediği sonucuna ulaşmış ve mevcut araştırmayı desteklemiştir (Akçayır, 2018; Yılmaz \& Batd1, 2016). AG'nin akademik başarıyı pozitif etkilemesinin nedenleri arasında zengin içerik sunarak öğrencilerin konuyu daha iyi anlamalarına yardımcı olması, daha iyi hatırlama ve uzun süreli bellekte kalıcıllı̆̆ sağlaması, öğrencilerin motor becerilerini geliştirmesi ve öğrenciler arasındaki işbirliğini artırması olarak sıralanabilir (Radu, 2014).

Araştırmanın meta-analiz sonuçlarını tamamlayıcı olarak tematik analizler de yapılarak AG'nin farklı boyutlara etkisi şeklinde çeşitli tema ve kodlar oluşturulmuştur. Duyuşsal boyuta katkıları açısından AG uygulamaları, konuların gerçek hayatla bağdaştırılmasına yardımcı olarak motivasyon artışına neden olduğu ve buna bağlı olarak da derse ve teknolojiye yönelik tutumu olumlu yönde değiştirdiği ortaya çıkmıştır (Delello, 2014; İbili \& Şahin, 2013; Kerawalla vd., 2006; Yen vd., 2012). Ayrıca AG uygulamalarının dersi ilginç ve farklı kılarak öğrencilerin sürece aktif katılmalarını sağladığı, meraklarını artırdığı, öğrenme sürecini eğlenceli, aktif ve etkili hale getirdiği belirlenmiştir (Ibáñez vd., 2016; Sirakaya, 2015;). 
Öğrenme ortamına katkıları açısından AG’nin gözle görülemeyen ve soyut yapıları üç boyutlu olarak görselleştirerek konuyu somutlaştırdığ ve karmaşık konuları daha anlaşılır hale getirdiği anlaşılmıştır (Lee, 2012; Somyürek, 2014; Walczak vd., 2006; Wu vd., 2013). Ayrıca AG’nin anlamayı ve öğrenmeyi kolaylaştırdığı, net ve ayrıntılı öğrenmeyi sağladığı, zor konuların anlaşılmasını sağladığı, faydalı ve etkili öğrenmeler sunduğu sonucuna ulaşılmıştır (Ivanova \& Ivanov, 2011; Walczak vd., 2006; Wu vd., 2013). Aktif öğrenme sürecinde önemli bir yere sahip olan AG uygulaması, tüm duyu organlarına hitap ederek daha kalıcı öğrenmeler sunduğu da belirtilmektedir (Baysan, 2015; Lee, 2012; Radu, 2014).

Mevcut çalışmada öne çıkan diğer bir görüş AG'nin doğrudan gözlemleme imkânı olmayan konuların öğretimi, tekrarlarla hata oranını düşürmesi, yenilikçi, gerçekçi, işbirliğine uygun ve etkileşimli ortamlar sunması gibi sınıf ortamına olumlu yönde katkılar sunmasıdır (Babur, 2016; Walczak vd., 2006; Yen vd., 2012). Bunun yanı sıra farklı etkinlikler yapma olanağı sunarak monotonluktan uzak daha hareketli ve renkli bir ders ortamı sunması uygulamanın diğer bir avantajı olarak ileri sürülmüştür (Fidan, 2018). Ayrıca gerçek dünyada yapılması kolay olmayan deneyleri, anlatılması karmaşı ve maliyeti yüksek olabilecek olan konuları öğretmeye yardımcı olmakta ve daha anlaşı1ır kılmaktadır (Baysan, 2015; Erbas \& Demirer, 2019; Küęük, 2015).

AG uygulamalarının eğitime ve diğer alanlara verdiği katkıların yanında birtakım sınırlılıklarının olduğunu da belirtmek gerekmektedir. Özellikle donanım yetersizliği, düşük internet hızı, uygulama üzerindeki nesneyi kameranın erken algılamaması ve bazen donmalar yaşanması AG kullanımında en büyük sınırlılıkların başında gelmektedir (Çömen, 2018; Küçük, 2015; Şentürk, 2018). Çalışmada gözlemlenen bir diğer sınırlılık ise uygulama esnasında web kamerası ve monitör kalibrasyonu sorunu olabilmektedir (Akkuş, 2016). Yapılan bu çalışmada elde edilen bir diğer sonuç ise AG uygulamasında içerik eksikliği, içerik geliştirmenin zaman alması, içeriğin anlaşılabilirliği ve kullanılabilirliğidir (Küçük, 2015). Bu tarz eksiklikleri gidermede zorlanacağını düşünen eğitmen ve öğrenen bireyler AG ortamına girmekten çekinebilmektedirler (Akkuş, 2016; Yuen vd., 2011). 